\title{
FACTORS AFFECTING THE ECONOMIC GROWTH IN THE MEKONG DELTA
}

\author{
Nguyen Kim Phuoc \\ Ho Chi Minh City Open University \\ Email: phuoc.nk@ou.edu.vn
}

(Received: 02/11/2015; Revised: 05/12/2015; Accepted: 07/12/2015)

\begin{abstract}
The objective of the study is to find out factors affecting the economic growth (GDP) of the 13 provinces/cities in the Mekong Delta. The study used secondary data from Statistical Yearbook of Statistical Office of 13 provinces cities in the Mekong Delta in the period of 2005 2014. The study included 12 independent variables which impact on the ability of the local GDP method, which has turned "economic crisis" to a dummy variable. With technical analysis panel regression, regression of GDP variables is made by macro factors and local characteristics. This study has found that the elements of economic crisis had a stronger impact and adverse effects on GDP. In addition, factors such as the state capital, private investment in the country, the situation of balancing the state budget revenues and expenditures, the open economy, inflation, and the total workforce retail sales also affect GDP. In particular, most of the variables are affected in the same way except two variables GDP which is inflation and balance of payment of the state budget (mixed impacts). From the research findings, some recommendations are proposed to promote economic growth of the Mekong Delta.
\end{abstract}

Keywords: GDP (Gross Domestic Product), crisis, Mekong Delta.

\section{Introduction}

Economic growth is an expectation of the nation and Vietnam are the one of them, the meaning is redundant in particular. The problem of economic growth has always been interested by researchers. The country has always put economic growth issues to the forefront. When the economy grows, people's lives are improving, besides, social is also developed ... The study of growth society different stages, different research areas will have different results due to local characteristics and the macroeconomic policies of each country, each phase will vary, so researchers often study the issues of the economic growth. Area Mekong Delta area is the main food supply of the country and exported to countries with a large volume of food. However, during the years, the economy has not really in Mekong Delta development, no more policies to boost the growth of this region. From this fact, research project "factors affecting the economic growth in the Mekong Delta" is performed, in order to determine the main factors affecting the GDP of the region and thereby suggest policies to promote economic growth of this region. The study uses econometric models to identify factors affecting the GDP of the provinces / cities of the Mekong Delta to clarify many research issues. Research content includes: Section 2 presents the theoretical overview; Section 3 
presents the model and methodology; Section 4 presents the results of research; Section 5 includes conclusions and policy recommendations.

\section{Theoretical overview}

\subsection{The theory of economic growth}

- Solow model (1956): The basic argument is the capital increase production only affecting the economic growth in the short term without compromising the long term, growth will reach "steady state". An economy with a higher savings rate will have higher levels of output which does not affect the economic growth in the long term (zero growth). Economic growth model of Solow initially considered an output (Y) is a function of capital (K) and labor (L).

- Keynes (1936), said that the growth and development of the economy of a country depends largely on government intervention through fiscal policy, monetary policy, public spending policy, public investment,... Aggregate demand ( $\mathrm{AD}$ ) of the economy is formed as follows:

$$
\mathrm{AD}=\mathrm{C}+\mathrm{I}+\mathrm{G}+\mathrm{N}-\mathrm{X}
$$

Where: $\mathrm{AD}$ is the aggregate demand of the economy, $\mathrm{C}$ is spending, $\mathrm{I}$ is investment, $\mathrm{G}$ is government spending, $\mathrm{N}$ is the total value of imports and $\mathrm{X}$ is the total value of exports. Government stimulus implemented in different ways including the method to stimulate consumption and production through increased public spending to increase aggregate demand and increase the impact of investment from the private sector (domestic and foreign). Neoclassical theory that increased the spending of government spending adversely which affects private consumption, restraining the growth of the economy because of resource allocation inefficient. Government invests too much can reduce competition, constrain investment from other sources such as private domestic investment and foreign investment,... thereby reduces the economic growth.
Samuelson and Nordhaus (2006) said that theory of Keynesian macro economics, typically Harrod - Domar. The origin of economic growth is due to increased capital ( $\mathrm{K}$ factor, capital) and put into production increase. Samuelson and Nordhalls (2006) inferred that once the economy is in a state of balanced growth that is transitioned to the unbalanced growth will increasingly unbalanced (economic instability). Meanwhile, theory of growth neoclassical building our model is based on two basic assumptions: (1) pricing flexibility and (2) the economy at full employment status. Accordingly, the economy is in a state of balanced growth which transitioned to unbalanced growth, it is only temporary, and it will quickly return to equilibrium.

Wagner's Law (1983) suggests that there is a close relationship between government spending and economic growth, especially in those countries during the industrialization and modernization of the country (Tanzi and Schuknecht (2000). Agree with Wagner's law, Tanzi and Schuknecht (2000) also said the country is in the period of industrialization and modernization of the country needs to spend more (focused on construction investment spending basic as transportation, electricity, water, bridges, ports, ...) to promote economic growth, attract private investment, especially foreign investment (including direct investment and indirect) .

\subsection{Previous studies on GDP}

According to Perkins et al (2006, Vol. 495), investment and growth clings relationship, despite the positive impact of investment on growth but the opposite relationship is not clearly disclosed. According to David (2007), the elements of the aggregate demand of the economy refers to volumes by consumers, businesses and government will use: GDP $=\mathrm{C}+\mathrm{I}+\mathrm{G}+\mathrm{XM}$. Hence, variation of these parts will cause a change of aggregate demand and thereby 
affecting economic growth.

Lin (1994) suggested that government how to allocate the state budget or public spending has a strong impact on economic growth. Public expenditure has an important role in the allocation of economic resources to ensure high economic efficiency. However, some others argue that FDI crowding out domestic investment (DI) and have an adverse effect on growth. Huang's study (2003), Braunstein and Epstein (2002) showed that FDI can substitute capital for long periods DI. Research of Acar et al. (2012) used the method to study GMM regression relationship between FDI and domestic investment (DI) for panel data of 13 countries in the Middle East and North Africa (MENA) in 1980 -2008 period). Research results prove overwhelming DI FDI.

Mankiw et al. (1990) uses Solow growth model to examine the volatility of international factors affecting economic growth. The observed variables in the model include the savings rate, private investment, population growth, per capita income, ... The results showed that keeping population growth and capital accumulation investments that affect economic growth.

Barro and Sala (1995) said that trade openness (TO is measured by the ratio of exports to GDP) is seen as a control variable in the regression of economic growth. Openness to trade can give a country greater access to technologies developed elsewhere and help them catch up adaptation process through advanced technology abroad. Openness of trade for importers makes it more accessible to foreign capital and increase the efficiency of domestic production.

Nguyen Van Phuc and Nguyen Dai Hiep (2011) study of factors affecting foreign investment attracted by the provinces/cities in Vietnam in 2006-2009 to 252 observations (4 years x 63 provinces/cities city). Data collected from the statistical yearbook of Vietnam (GSO) and the PCI report annually.
The study results showed that total industrial products ( $1 \%$ significance level), legal institutions (1\% significance level) and infrastructure (5\% significance level) and business support services (level of significance $10 \%$ ) have an impact on attracting FDI in the provinces/cities of Vietnam.

Nguyen Minh Tien (2014), a study on "foreign direct investment and economic growth in the region of Vietnam". The results showed that the variables have a positive impact on GD, which are: private investment, human resources, regular expenditures, infrastructure and economic openness. State budget revenues affect to GDP of the North and of the South Sound positively.

\section{Models and Research Methods}

\subsection{Models}

Research model as follows:

$\mathrm{LN}_{-} \mathrm{GDP}_{i \mathrm{it}}=\beta_{0}+\beta_{1}^{*} \mathrm{LN}_{-} \mathrm{FDI}_{\mathrm{it}}+$ $\beta_{2} * \mathrm{LN}_{-} \mathrm{BRE} \mathrm{it}_{\mathrm{it}}+\beta_{3} * \mathrm{LN} \_\mathrm{INTATE}$ it $+\beta_{4} * \mathrm{LN}-$ ${ }_{\text {INPRI }}+\beta_{5} * \mathrm{OPEN}_{\mathrm{it}}+\beta_{6} * \mathrm{CPI}_{\mathrm{it}}+\beta_{7} * \mathrm{LN}-$ ${ }_{2} \mathrm{LABOR}_{\mathrm{it}}+\beta_{8} * \mathrm{LN}_{-} \mathrm{TEL}_{\mathrm{it}}+\beta_{9} * \mathrm{LN} \_\mathrm{SALE}_{\mathrm{it}}+$ $\beta_{10} *$ COSTMAR $_{\mathrm{it}}+\beta_{11} *$ POPRI $_{\mathrm{it}}+\beta_{12} *$ CRISIS

With i: Representing local $\mathrm{i}$;

$\mathrm{i}=1 ; 2 ; 3 ; 4 ; \ldots . . ; 63$

$\mathrm{t}$ : Representing year $\mathrm{t}$;

$\mathrm{t}=1 ; 2 ; 3 ; 4$ (10 years from 2005 to 2014)

u: Error

$\beta_{0}$ : Original Score

$\beta_{1} \ldots . .12$ : The estimated coefficient of the independent variable.

Object and scope of the study: 13 provinces/cities of MRD (13 provinces/cities) during 10 years (2005-2014). The total number of observations is 130 (13 provinces/cities x 10 years). Data collected from the Statistics Yearbook of PSO in 13 provinces/cities and evaluations Provincial Competitiveness Index (PCI) of 13 provinces/cities in 10 years (collected from site VCCI electronics at: www.vcci.com.vn). The number of 130 valid observations. 
Table1. Description of the variables in the model study

\begin{tabular}{|c|c|c|c|}
\hline $\begin{array}{l}\text { Name of } \\
\text { variables }\end{array}$ & Defining Variables & $\begin{array}{c}\text { Theory and previous research } \\
\text { related }\end{array}$ & $\begin{array}{l}\text { Expected } \\
\text { sign }\end{array}$ \\
\hline LN_FDI & $\begin{array}{l}\text { LN_TONGFDI: the total foreign } \\
\text { direct investment (unit: million) } \\
\text { registered annually in the local } \\
\text { Vietnam, including increased } \\
\text { capital (take LN). }\end{array}$ & $\begin{array}{l}\text { Keynes (1936), Solow (1956), } \\
\text { Heckscher và Ohlin (1991) }\end{array}$ & + \\
\hline LN_GDP1 & $\begin{array}{l}\text { LN_GDP1: the total annual gross } \\
\text { domestic product in the locality of } \\
\text { Vietnam (unit: billion VND), } \\
\text { calculated at } 2010 \text { prices (take LN). }\end{array}$ & $\begin{array}{l}\text { Keynes (1936), Solow (1956), } \\
\text { Heckscher và Ohlin (1991) }\end{array}$ & + \\
\hline LN_BRE & $\begin{array}{l}\text { Balancing revenues and } \\
\text { expenditures (total revenues - } \\
\text { total expenditures), local budgets } \\
\text { (Unit: Billion VND) (take LN). }\end{array}$ & $\begin{array}{l}\text { Keynes (1936), Wagner (1983), } \\
\text { Afonso et al (2010), Nguyen } \\
\text { Minh Tien (2014) }\end{array}$ & - \\
\hline LN_INSTATE & $\begin{array}{l}\text { Total investment of state (unit: } \\
\text { VND billion) into the local (take } \\
\text { LN). }\end{array}$ & $\begin{array}{l}\text { Solow (1956), Anwar and } \\
\text { Nguyen (2010) }\end{array}$ & $+/-$ \\
\hline LN_INPRI & $\begin{array}{l}\text { Total investment of the private } \\
\text { sector in nation (unit: VND } \\
\text { billion) into the local (take LN). }\end{array}$ & $\begin{array}{l}\text { Solow (1956), Acar and et al } \\
\text { (2008), Anwar and Nguyen } \\
(2010) ;\end{array}$ & $+/-$ \\
\hline OPEN & $\begin{array}{l}\text { The openness of the economy } \\
\text { (export-import turnover / GDP) }\end{array}$ & $\begin{array}{l}\text { Ricardo (1951), Hymer (1976), } \\
\text { Heckscher and Ohlin (1991), } \\
\text { Nguyen Phi Lan (2006) }\end{array}$ & + \\
\hline CPI & $\begin{array}{l}\text { Consumer price index or the rate } \\
\text { of inflation in each local }(\%)\end{array}$ & Globerman and Shapiro (2003) & - \\
\hline LN_LABOR & $\begin{array}{l}\text { The labor force is working (unit: } \\
\text { million people) are therefore in } \\
\text { total employment from } 15 \text { years } \\
\text { and older are employed (take LN). }\end{array}$ & $\begin{array}{l}\text { Ricardo (1951), Solow (1956), } \\
\text { Solomon (2011) }\end{array}$ & + \\
\hline LN_TEL & $\begin{array}{l}\text { The number of fixed telephone } \\
\text { subscribers (Unit: Number of } \\
\text { subscribers/1000 inhabitants) is } \\
\text { one of the variables representing } \\
\text { the variable infrastructure group } \\
\text { of local. }\end{array}$ & $\begin{array}{l}\text { Demirhan and Masca (2008), } \\
\text { Nguyen Minh Tien (2014) }\end{array}$ & + \\
\hline LN_SALE & $\begin{array}{l}\text { Total retail sales (unit: VND } \\
\text { billion) in the local - variable } \\
\text { representing the market size in } \\
\text { the province/city. }\end{array}$ & $\begin{array}{l}\text { Ricardo (1951), Hymer (1976), } \\
\text { Heckscher and Ohlin (1991) }\end{array}$ & + \\
\hline COSTMAR & The cost to enter the market & Dunming $(1977,1973,1981)$ & + \\
\hline
\end{tabular}




\begin{tabular}{|l|l|l|c|}
\hline \multicolumn{1}{|c|}{$\begin{array}{c}\text { Name of } \\
\text { variables }\end{array}$} & \multicolumn{1}{|c|}{ Defining Variables } & \multicolumn{1}{|c|}{$\begin{array}{c}\text { Theory and previous research } \\
\text { related }\end{array}$} & $\begin{array}{c}\text { Expected } \\
\text { sign }\end{array}$ \\
\hline & $\begin{array}{l}\text { (unit: point) is variable to } \\
\text { represent the local characteristics }\end{array}$ & & \\
\hline POPRI & $\begin{array}{l}\text { Support businesses or economic } \\
\text { development policies of private } \\
\text { (unit: point) is variable } \\
\text { representing local characteristics }\end{array}$ & $\begin{array}{l}\text { Dunming (1977,1973, 1981), } \\
\text { Nguyen Van Phuc and Nguyen } \\
\text { Dai Hiep (2011) }\end{array}$ & + \\
\hline CRISIS & $\begin{array}{l}\text { The economic crisis, this variable } \\
\text { = } 1 \text { if the value of FDI registered } \\
\text { before 2010 and receive value }=0 \\
\text { if registered from 2010 to 2014. }\end{array}$ & $\begin{array}{l}\text { Senturk (2010), Nguyen Minh } \\
\text { Tien (2014) }\end{array}$ & \\
\hline
\end{tabular}

Source: Author (2015).

\subsection{Research Methods}

The author used the technique to build regression table regression model to test the research hypotheses set out to examine the influence of these factors and affect GDP level of city/province. Especially the impact of the global economic crisis is considered as to the economic growth (GDP) of the provinces/cities. The research sample included 13 cities/provinces in 10 years (from 2005 to 2014) with a total of 130 observations. Source data are collected from the General Statistics Office of Vietnam (www.gso.gov.vn).

Regression model between the dependent variable (GDP) with the variable characteristics of the economy and put more turn crisis (dummies) to assess the impact of these variables on GDP. The author will in turn perform the regression model as model Pooled (pooled OLS regression model -Pooled), model fixed effects model (regression) - FEM fixed effects) of units Cross, from which to select a suitable model.

Wald test for the purpose of determination of the origin of the released unit cross (13 provinces/cities ) is equal or not, this means launching the original coefficients of the study subjects are equal (ie no individual characteristics between provinces/cities). If equal is coefficient case-axis satisfactory and unchanged coefficient slope, or Pooled model is appropriate.

Verification of conformity of the regression coefficiences considers the linear relationship between independent variables and the dependent variable. The model is considered inappropriate when all the coefficient regression is zero and the model is considered appropriate to have at least one non-zero coefficient regression.

Accreditation error variance changes the method Breusch \& Pagan (1979). Based on the value of the index Prob Chi-square testing to decide to accept or reject the hypothesis $\mathrm{H}_{0}$. If Prob $>\alpha=5 \%$, not reject $\mathrm{H}_{0}$ hypothesis, is model of no correlation error occurred change.

Testing of serial correlation: According to Wooldridge (2002), we can test the type 1 serial correlation by the regression residuals obtained in models with variable delay its origin as model $\varepsilon t=\rho \varepsilon(t-1)+u \neg t$ and then proceed to the Wald test for this model. If there is serial coefficient correlation $\rho$ level 1 will receive a value of -0.5 . Therefore, the hypothesis of the Wald test $\mathrm{H}_{0}$ is $\rho=-0.5$, ie serial correlation occur Career 1. If $\mathrm{p}$-value $\leq$ value of significant level $\alpha$, then we reject the hypothesis $\mathrm{H}_{0}$, there serial correlation phenomenon that does not happen and vice versa. 


\section{Analysis of findings}

\subsection{Statistical analysis described}

Table 2. Statistics describing the value of the variables in the model

\begin{tabular}{|l|r|r|r|r|}
\hline \multicolumn{1}{|c|}{ Variable } & Minimum & Maximum & \multicolumn{1}{|c|}{$\begin{array}{c}\text { Mean } \\
\text { Std. }\end{array}$} & Deviation \\
\hline The labor force is working (unit: million people) & 407.50 & $1,278.26$ & 743.56 & 223.74 \\
\hline $\begin{array}{l}\text { The total annual gross domestic product in the } \\
\text { locality of Vietnam (Unit: billion VND) }\end{array}$ & $7,836.49$ & $68,536.00$ & $27,019.75$ & $13,864.84$ \\
\hline Total investment of state (unit: VND billion) & 265.50 & $14,246.00$ & $3,197.09$ & $3,119.45$ \\
\hline The total foreign direct investment (unit: million) & 0.00 & $6,635.83$ & 658.84 & $1,251.64$ \\
\hline Total investment of the private sector in nation & 78.30 & $23,048.00$ & $6,043.65$ & $4,587.04$ \\
\hline Total retail sales (unit: VND billion) & $2,664.08$ & $49,559.26$ & $19,470.07$ & $11,755.08$ \\
\hline The openness of the economy & 0.59 & 11.39 & 2.65 & 1.96 \\
\hline $\begin{array}{l}\text { Consumer price index or the rate of inflation in } \\
\text { each local (\%) }\end{array}$ & 99.31 & 128.16 & 108.34 & 5.97 \\
\hline The number of fixed telephone subscribers & 0.51 & 46.84 & 8.04 & 7.17 \\
\hline $\begin{array}{l}\text { Balancing revenues and expenditures (unit: VND } \\
\text { billion) }\end{array}$ & $-86,166.00$ & $1.577,14$ & -1.503 .75 & $7,683.13$ \\
\hline The cost to enter the market (point) & 4.5264 & 9.5362 & 7.929641 & 1.0219410 \\
\hline $\begin{array}{l}\text { Support businesses or economic development } \\
\text { policies of private (point) }\end{array}$ & 1.3972 & 8.6795 & 4.703405 & 1.3231363 \\
\hline Valid N (listwise) = 130; & & & & \\
\hline
\end{tabular}

Source: Author (2015).

GDP (at current prices 2010) average 13 city/MD with low value. The highest value of this area has 68,536 billion, with the lowest value of $7,836.49$ billion. GDP value in 10 years (2005-2014) of the whole Mekong Delta region is $27,019.75$ billion. This is a modest figure compared with other regions. The value of regional GDP is low MRD, showed no real development of Mekong Delta Economy, the contribution of this sector which is to the overall growth of Vietnam's economy is not high.

Invested by the domestic private sector has the lowest value MRD which was 78.3 billion, the highest was 23,048 billion, an average of 13 provinces/cities for 10 years (2005-2014) has only 6,043.65 billion. Because this region has low investment, not shown, economic development should seek regional energy private investment capital is relatively low compared with other sources.

State investment capital of almost the main source of investment capital of the whole Mekong Delta region. Invested by the lowest state of up to 265.5 billion - 4 times higher private investment in the country. State investment capital invested in this area can reach 14,246 billion, the average rate of about $3,197.09$ billion. State investment capital in the Mekong Delta region in comparison with 
other capital sources is high but not high compared with other regions, this fund has not generated much momentum for the economic development of the Mekong Delta.

Foreign investment capital in the Mekong Delta region has five no (zero investment this is the lowest). This capital is the highest to date in 2014 was $6,635.83$ million, the average of 13 provinces/cities in the period 2005 to 2014 is 658.84 million. This figure is relatively small compared to the total amount of FDI investments in Vietnam. This can stem from many causes objective and subjective causes, subjective and customer issues. However, standing on the investor base, investors are concerned about the profitability of capital, development potential of the business in the short and long term ... so foreign investors have not invest in this area because they have not seen the aforementioned points. Investors can also be attracted by the policies and structure of the local economy, policy makers Investors can also be attracted.

Retail sales of the Mekong Delta region has the lowest value in the period $2005-2014$ was 2,664.08 billion, the highest level is only 49,559.26 billion and anerage of 19,470.07 billion. Size of the market expressed in part through the retail sales of goods and services, looking at retail sales figures show that the region's economic Mekong Delta region has not really developed, the level of consumer goods and services still low.

Aperture economy reached average level. In fact, the city/Mekong Delta mainly exports aquaculture products (fish fillets, shrimp, fish,...) which do not have high export value. However, the Mekong Delta province to import a lot of machinery, aqua feed, inputs... This situation should improve both the export and import direction.

Consumer price index (CPI) in the Mekong Delta region is more than the country without much fluctuation. Consumer price index on average over the period $2005-2014$ was $108.34 \%, 128.16 \%$ is highest. Thus, the CPI this area than the country intended to be lower. This is due to the sales of goods and services are not high, consumption is limited to the volatility of the price index is not much. Percentage phone/thousand people are a variable representing the infrastructure of the Mekong Delta. There were years, this ratio is very low, the lowest was $0.59 \%$. This figure is the highest in the period $2005-2014$ was $46.84 \%$ and an average of $8.04 \%$. Thus, the infrastructure of the area has not really developed well despite recent years have significantly improved, rapid growth.

Fiscal situation of the provinces/Mekong Delta showed that local budgets are mostly collected less and spent more, generally budget deficits. Average 13 cities/total revenues less than 5 trillion (4840.34 billion), while total spending on average up to $6,327.09$ billion. Therefore, the local budget imbalanced most, an average budget deficit of 1,500 billion, which is the main thing affects capital accumulation for the local investment.

Cost of market entry and economic development policies are two private component variables of PCI. Two variables are included to determine the impact of policies and investment environment of the province that affect economic growth and attracting FDI or not. According to statistical results (Table 4) this indicator is rated quite high, reflecting the views of the index number "market entry cost" average nearly 8 points, the "policies for private economic development" with an average score of 5 points. This result shows that the business has not appreciated "the policy development of private economy" of the local. This may well be one of the reasons private and foreign enterprises and foreign invested less in this area.

\subsection{Results of regression analysis}

Results of regression analysis the 
dependent variable (GDP) as the independent variables OLS estimation method using pooled data (model Pooled_ex), method of fixed effects (model FEM_ex) of the units are able to cross shown in Table 3 below:

Table 3. The test results choose between POOL OLS and FEM

\begin{tabular}{|l|c|c|c|}
\hline Redundant Fixed Effects Tests \\
\hline Effects Test & Statistic & d.f & Prob. \\
\hline Cross-section F & 49.060436 & $(12,105)$ & 0.0000 \\
\hline Cross-section Chi-square & 245.455030 & 12 & 0.0000 \\
\hline
\end{tabular}

Note: $* * *$ Prob. $=1 \%$, ** Prob. $=5 \%$, Prob. $=10 \%$.

Source: Author (2015)

The test results give valuable Wald Chi- is a difference between coefficient axis and square $=245.455030$ and Prob $=0.0000<\alpha=$ the dependent variable, so there are more 0.05 to reject the null hypothesis $\mathrm{H}_{0}$, so, there suitable model FEM and model POOL.

Table 4. Cross-section fixed effects test equation

\begin{tabular}{|c|c|c|c|}
\hline Variable & Coefficient & Std. Error & $\begin{array}{l}\text { Compared with } \\
\text { research } \\
\text { expected }\end{array}$ \\
\hline LN_FDI & $\begin{array}{c}0.001182 \\
(0.7086)\end{array}$ & 0.003153 & True \\
\hline LN_BRE & $\begin{array}{c}-0.003771 * * * \\
(0.0009)\end{array}$ & 0.001102 & True \\
\hline LN_INPRI & $\begin{array}{c}0.049273 * * * \\
(0.0004)\end{array}$ & 0.013436 & True \\
\hline LN_INSTATE & $\begin{array}{c}0.075631 * * * \\
(0.0000)\end{array}$ & 0.012996 & True \\
\hline OPEN & $\begin{array}{c}0.011303 * * * \\
(0.0072)\end{array}$ & 0.004121 & True \\
\hline CPI & $\begin{array}{c}-0.001576^{* * *} \\
(0.0059)\end{array}$ & 0.000561 & True \\
\hline LN_LABOR & $\begin{array}{c}1.187261 * * * \\
(0,0000)\end{array}$ & 0.163702 & True \\
\hline LN_TEL & $\begin{array}{c}0.004348 \\
(0.4574)\end{array}$ & 0.005830 & True \\
\hline
\end{tabular}




\begin{tabular}{|c|c|c|c|}
\hline Variable & Coefficient & Std. Error & $\begin{array}{c}\text { Compared with } \\
\text { research } \\
\text { expected }\end{array}$ \\
\hline LN_SALE & $\begin{array}{c}0.254182^{* * *} \\
(0.0000)\end{array}$ & 0.020985 & True \\
\hline COSTMAR & $\begin{array}{c}-0.000929 \\
(0.8565)\end{array}$ & 0.005122 & True \\
\hline POPRI & $\begin{array}{c}-0.002512 \\
(0.4490)\end{array}$ & 0.003305 & True \\
\hline CRISIS & $-0.071773 * * *$ \\
$(0.0000)$ & 0.014177 & True \\
\hline Total panel observations & \multicolumn{2}{|c|}{130} & \\
\hline R-squared & 0.994287 & \\
\hline Adjusted R-squared & 0.992981 & \\
\hline Durbin-Watson stat & 1.205494 & \\
\hline F-statistic & 761.4441 & & \\
\hline
\end{tabular}

Note: $* * *$ Prob. $=1 \%, * *$ Prob. $=5 \%$, Prob. $=10 \%$.

Source: Author (2015).

\subsection{Accreditation suitability model}

Table 5. The test results multicollinearity

\begin{tabular}{|c|c|c|}
\hline \multirow{2}{*}{ Variable } & \multicolumn{2}{|c|}{ The dependent variable is GDP } \\
\cline { 2 - 3 } & VIF & Tolerance \\
\hline LN_FDI & 2.14 & 0.4670 \\
\hline LN_BRE & 1.61 & 0.6200 \\
\hline LN_INPRI & 4.79 & 0.2087 \\
\hline LN_INSTATE & 3.24 & 0.3085 \\
\hline OPEN & 1.55 & 0.6439 \\
\hline CPI & 1.08 & 0.9217 \\
\hline LN_LABOR & 3.33 & 0.3004 \\
\hline LN_TEL & 1.83 & 0.5453 \\
\hline LN_SALE & 7.04 & 0.1419 \\
\hline
\end{tabular}




\begin{tabular}{|c|c|c|}
\hline \multirow{2}{*}{ Variable } & \multicolumn{2}{|c|}{ The dependent variable is GDP } \\
\cline { 2 - 3 } & VIF & Tolerance \\
\hline COSTMAR & 1.33 & 0.7501 \\
\hline POPRI & 1.37 & 0.7318 \\
\hline CRISIS & 1.85 & 0.5399 \\
\hline
\end{tabular}

Source: Author (2015).

Gujarati (2012) argues that there are two commonly used signs to recognize signs of multicollinearity between the variables in the model which is to use the correlation coefficient pair and VIF. VIF coefficients are less than 10, the biggest variable is the variable VIF total retail sales by 0.7 only. At the same time, the tolerances of the variables are small. Thus, the variables in the model no multicollinearity phenomenon occurs. To ensure the reliability of the results, selected model (FEM) was conducted testing at the step (testing autocorrelation/serial correlation, control error variance change). The test results are as follows:

Table 6. Testing autocorrelation

\begin{tabular}{|c|c|c|c|}
\hline & t-statistic & F-statistic & Chi - square \\
\hline \multirow{4}{*}{ GDP } & 14.96993 & 224,0988 & 224,0988 \\
& $(0.000)$ & $(0.000)$ & $(0.000)$ \\
\cline { 2 - 4 } & & Value $=$ & Std. Error $=$ \\
& $0.5+\mathrm{C}(1)$ & 1.054314 & 0.070429 \\
\hline
\end{tabular}

The author used the Wald test in case of error variance to test the changes to the chosen model, inspection results (Table 6) showed no error variance phenomenon changed and no similar phenomenon the string in selected models.

F-statistic for the results of Prob (Fstatistic) $=0.000<\alpha=0.05$, so we reject $\mathrm{H}_{0}$ hypothesis, the hypothesis $\mathrm{H}_{1}$ : model study is appropriate. Besides, the authors also found that $\mathrm{R}^{2}$ calibrate the model by 0.992981 . This means that the above model, the independent variables within the bank may be about 99.29\% explain the variations in GDP.

\subsection{Discuss findings}

Variable fiscal balance has adverse effects for the dependent variable (GDP). Empirical research results matching expectations and initial signs consistent with previous studies (Nguyen Minh Tien, 2014). Budget expenditures are as much increasing as economic growth is. In fact, the majority of provinces/cities in Vietnam are unbalanced budget (expenditures and revenues) except some large cities. According to Keynes's theory (1936), the government increased expenditure to help the economic growth, in terms of budget revenue increasing budget revenue, the increase will not lead to budgetary imbalances. Thus, the budget imbalance (deficit) has the effect of promoting economic growth. Budget imbalance does not mean that economic growth worsens the economic growth to do better. This is particularly appropriate for developing countries like Vietnam. 
Private capital of investment has a positive impact on GDP of the provinces/MD. Research results are entirely consistent with reality and consistent with previous studies (Acar et al (2008), Nguyen Minh Tien (2014)). According to Solow (1956), which is an important input factor, increasing the amount of capital in general helps the economy grow. According to Keynesian theory of aggregate demand (1936), investments increased (ceteris paribus) will help aggregate demand increase (Y increases). In capital of investment, private investment in the country account for a significant proportion of the total investment in the economy. In particular, private investment in the country increased rapidly after the world economic crisis.

Investments of the State has strong impacts on economic growth of the city/ Mekong Delta. The study results fit with previous studies (Acar et al (2008), Nguyen Minh Tien (2014)) and in accordance with the expected mark of the research model. Similar to private investment in the country, the city/MRD for not attracting FDI, the percentage of the state capital is also a high proportion of the total investment. According to Solow (1956) and Keynes (1936), investments increased (ceteris paribus) will help the economy grow thanks to the capital element.

The openness of the economy has a positive impact on economic growth in the Mekong Delta. This result is consistent with the findings of Nguyen Phi Lan (2006), Nguyen Minh Tien (2014). According to Keynes's theory (1936), turnover increased imports, especially increasing exports (net export becomes positive or surplus) will help the economy grow (assuming the elements paribus). The largest export revenues of the provinces/cities in the region, although in terms of value of regional imports and exports lower in other regions. Therefore, the opening of the economy has a great influence on the economic growth of the Mekong Delta appropriately.

Regarding consumer price index (CPI): CPI variable works mixed with the dependent variable (GDP) as a result consistent with practical and consistent with initial expectations point (1\% significance level) Subject Keynes (1936), inflation (CPI) to reduce consumption $(\mathrm{C})$, reduced investment (I) due to raising interest rates and thereby reduce economic growth even more. In periods of high inflation economy, people tend to reduce consumption by higher commodity prices, wages and incomes do not increase or increases do not correspond, the savings rate fell. Saving the funds available for investment, so investment also fell. Also, due to falling consumption, business investment fell due to reduced consumer goods, ... thereby reducing economic growth.

Variable labor force is working as a variable with the strongest impact on economic growth of the city/MRD. This shows that the labor force has made great contributions in economic growth. According to Solow (1956), economic growth based on two main factors is capital and labor. Labor factors have role in promoting economic growth and city/MRD is appropriate. Therefore, the increase in the labor force has important implications for regional economies in labor-intensive as the Mekong Delta.

Regarding the total retail sales of goods: This is powerful variable 2 nd of 8 statistically significant variables (represented by the regression coefficient $\mathrm{B}=0.254182$ ) to GDP of provinces/MD. According to Keynes, consumption increased ( $\mathrm{C}$ increase) resulting in total demand. Also, the investors have the choice of investing their many advantages, including the advantage of consuming markets.

The economic crisis has adverse effects for economic growth of the local (regression 
coefficient of this variable is negative). According to Keynes (1936), when the economy is experiencing the shock as the global economic crisis, factors relating to foreign bureaucracy such as import-export (mainly export) will be severely reduced, so the growth of the local economy will decline.

\section{Conclusion and policy recommendations}

\subsection{Conclusion}

Economic growth of the Mekong Delta Which is dependent on factors in the model 8/12 is: balancing revenues and expenditures, total invesment of the private section in nation, the open economy, consummer price Index, labor force is working, total retail sales of goods and economic crisis. Two variable nature of the local characteristics of 2 variables of PCI components are the cost of market entry and economic development policies of private no impact on GDP. The nature variables (?) such as CPI, Scientific LN_BRE and most have negative impacts on dependent variables, ie reduced economic growth of 13 the local in Mekong Delta.

\subsection{Policy recommendations}

Factor of capital (including domestic and foreign capital) are necessary and important for the country even though country has developed, developing or underdeveloped. Each phase of the economy, which affects the level of different economies, is an indispensable element. In terms of internal resources as Vietnam is not enough now, funds from foreign investors play an important role. Capital investment in the future should focus on investment and development of transport infrastructure (both roads and waterways), infrastructure development, communications (phone, internet). The capital required for infrastructure development because of the large current Vietnam's infrastructure is not complete, especially as the Mekong Delta region. Investment in infrastructure should not invest too much but must calculate the economic development of the region in the long term (decades later), avoid roads just completed several years continued to expand, upgrade make considerable cost and low efficiency.

One thing worth mentioning is that FDI lat ace signs of private investment in the country, while the state's capital and FDI have correlated together. Therefore, the government has invested more capital into this region which is quite strong spillovers. Invested by domestic private positive impact to the regional economic growth, thus increasing the state's investment is beneficial in many aspects of the nation. Under current practice, the Mekong Delta region has great potential and advantages to develop the food industry, tourism and the regional importance of food security of Vietnam and important role in ensuring security of world food security. So linking of the essential and urgent implementation is more effective. Government plays an important role in the overall planning of economic zones based on the economic advantages of each region, should not be based on administrative boundaries to avoid the fragmentation of economic development region. In the long term, governments/ province in the Mekong Delta should implement the policies for training to have quality human resources which meet the needs of investors... meet the needs of investors at home and abroad.

\section{REFERENCES}

Acar, S., Eris, B. \& Tekce, M. (2012). The effect of foreign direct investment on domestic investment: Evidence from MENA countries. European Trade Study Group (ETSG) 14th Annual Conference, September, Leuven. 
Afonso, A., Schuknecht, L. \& Tanzi, V., (2010). Public sector efficiency: evidence for new EU member states and emerging markets. Applied Economics, 42, 17, 2147-2164.

Anwar, S. \& Nguyen, L. P., (2010). Foreign direct investment and economic growth in Vietnam. Asia Pacific business review, 16, 1-2, 183-202.

Barro, R. \& Sala, X., (1995). Economic, Growth, McGraw-Hill.

Braunstein, E. \& Epstein, G., (2002). Bargaining power and foreign direct investment in China: Can 1.3 billion consumers tame the multinationals?

Breusch, T. S., and Pagan, A. R., (1979). A Simple Test for Heteroscedasticity and Random Coefficient Variation. Econometrica, Vol. 47, No. 5 (Sep., 1979), pp. 1287-1294.

David B., Stanley F., Rudiger D., (2007). Economics, teacher group in the department of Economics - National Economics University translated, Staticstic Publisher, Hanoi.

Dunning, J. H. \& Buckley, P. J., (1977). International production and alternative models of trade. The Manchester School, 45, 4, 392-403.

Dunning, J. H., (1973). The determinants of international production. Oxford economic papers, Vol. 25, No. 3 (Nov., 1973), pp. 289-336.

Dunning, J. H., (1981). Explaining the international direct investment position of countries: towards a dynamic or developmental approach. Weltwirtschaftliches Archiv, 117, 1, 30-64.

Globerman, S. \& Shapiro, D., (2003). Governance infrastructure and US foreign direct investment. Journal of International Business Studies, 34, 1, 19-39.

Gujarati, D. N., (2012). Basic econometrics, Tata McGraw-Hill Education.

Heckscher, E. F. \& Ohlin, B. G., (1991). Heckscher-Ohlin trade theory, The MIT Press.

Hymer, S. H., (1976). The international operations of national firms: A study of direct foreign investment, MIT press Cambridge, MA.

Lin, S. A., (1994). Government spending and economic growth. Applied Economics, 26, 1, 83-94.

Mankiw, N. G., Romer, D. \& Weil, D. N. 1990. A contribution to the empirics of economic growth. National Bureau of Economic Research.

Nguyen Minh Tien (2014). Foreign direct investment and economic growth in the regions of Vietnam, doctoral thesis in Economics, University of Economics. Ho Chi Minh.

Nguyen Phi Lan (2006). Foreign Direct Investment and its linkage to economic growth in Vietnam: A Provincial Analysis, Centre for Regulation and Market Analysis University of South Australia, Adelaide, SA 5001, Australia.

Nguyen Van Phuc and Nguyen Dai Hiep (2011). Factors affecting foreign investment attracted by the provinces/cities in Vietnam: A cross-analysis of data. Journal of Science Ho Chi Minh City Open City University, No. 02 (2) 2011, page 9 -19. 
Ricardo, D. (1951). On the Principles of Political Economy and Taxation, 1st edn 1817, 3rd edn 1821. In vol. I of The Works and Correspondence of David Ricardo, edited by Piero Sraffa with the collaboration of Maurice H. Dobb. Cambridge: Cambridge University Press.

Samuelson, P. A. \& Nordhaus, W. D., (2006). Economic [Economic Theory] (Full Set 2 Episode). Volume 2.

Senturk, S. S., (2010). Total Factor Productivity Growth in Turkish Manufacturing Industries: A Malmquist Productivity Index Approach. Master of Science Thesis. Royal Institute of Technology, School of Architecture and the Built Environment.

Solomon, E. M., (2011). Foreign direct investment, host country factors and economic growth. Ensayos Revista de Economia, 30, 1, 41-70.

Solow, R. M., (1956). A contribution to the theory of economic growth. The quarterly journal of economics, 65-94.

Tanzi, V. \& Schuknecht, L., (2000). Public spending in the 20th century: A global perspective, Cambridge University Press.

Wagner, A., (1983). Grundlegung der politischen Okonemie, 3 rd ed., Leipzig.

Wooldridge, Jearey M., (2002). Econometric Analysis of Cross Section and Panel Data, The MIT Press Cambridge, Massachusetts, London, England. 